\title{
Clinical practice guideline on diagnosis and treatment of hyponatraemia
}

\section{Goce Spasovski, Raymond Vanholder ${ }^{1}$, Bruno Allolio ${ }^{2}$, Djillali Annane ${ }^{3}$, Steve Ball ${ }^{4}$, Daniel Bichet ${ }^{5}$, Guy Decaux ${ }^{6}$, Wiebke Fenske ${ }^{2}$, Ewout J Hoorn ${ }^{7}$, Carole Ichai ${ }^{8}$, Michael Joannidis ${ }^{9}$, Alain Soupart ${ }^{6}$, Robert Zietse ${ }^{7}$, Maria Haller ${ }^{10}$, Sabine van der Veer $^{11}$, Wim Van Biesen ${ }^{1}$ and Evi Nagler ${ }^{1}$ on behalf of the Hyponatraemia Guideline Development Group}

State University Hospital Skopje, Skopje, Macedonia, ${ }^{1}$ Ghent University Hospital, Ghent, Belgium, ${ }^{2}$ Würzburg University Hospital, Würzburg, Germany, ${ }^{3}$ Raymond Poincaré Hospital, University of Versailles Saint Quentin, Paris, France, ${ }^{4}$ Newcastle Hospitals and Newcastle University, Newcastle, UK, ${ }^{5}$ Sacré-Coeur Hospital, University of Montreal, Montreal, Quebec, Canada, ${ }^{6}$ Erasmus University Hospital, Brussels, Belgium, ${ }^{7}$ Erasmus Medical Centre, Rotterdam, The Netherlands, ${ }^{8}$ Nice University Hospital, Nice, France, ${ }^{9}$ Innsbruck University Hospital, Innsbruck, Austria, ${ }^{10} \mathrm{KH}$ Elisabethinen Linz, Linz, Austria and ${ }^{11}$ Amsterdam Medical Centre, Amsterdam, The Netherlands
Correspondence should be addressed to The Editorial office, European Journal of Endocrinology;

Email: eje@bioscientifica.com

The journal and the authors apologise for errors in this article published in the March issue (vol 170, pp G1-G47).

\section{Correction 1}

In column 2 of Table 7 on page G16, the last disorder under Pulmonary disorders should be Respiratory failure associated with positive-pressure breathing and not as published.

\section{Correction 2}

On page G20, only SI units should be used in the equation for estimates of the serum sodium concentration corrected for the presence of hyperglycaemia and not as published. The correct equation is as follows:

Corrected serum $\left(\mathrm{Na}^{+}\right)=$measured $\left(\mathrm{Na}^{+}\right)+2.4 \times \frac{(\text { glucose }(\mathrm{mmol} / \mathrm{l})-100(\mathrm{mmol} / \mathrm{l})}{100 \mathrm{mmol} / \mathrm{l}}$

Corrected $\left(\mathrm{Na}^{+}\right)=$measured $\left(\mathrm{Na}^{+}\right)+2.4 \times \frac{(\text { glucose }(\mathrm{mmol} / \mathrm{l})-5.5(\mathrm{mmol} / \mathrm{l})}{5.5 \mathrm{mmol} / \mathrm{l}}$

(c) 2014 European Society of Endocrinology, European Society of Intensive Care Medicine, European Renal Association-European Dialysis and Transplant Association
Published by Bioscientifica Ltd. Printed in Great Britain 